\title{
Oppose and Propose! Lessons from Movement for New Society by Andrew Cornell. AK Press, 2011. Pp. 210. \$12 (paperback). ISBN: 978-1849350662
}

\section{Reviewers: Julie Cristol and T. L. Hill III ${ }^{1}$}

[Article copies available for a fee from The Transformative Studies Institute. E-mail address: journal@transformativestudies.org Website: http://www.transformativestudies.org (C2011 by The Transformative Studies Institute. All rights reserved.]

Oppose and Propose is an attractively packaged, field-guide-sized "organizational biography" of Movement for a New Society (MNS), an organization devoted to nonviolent social change that flourished in Philadelphia between 1971 and 1988. The book's design suggests that it is intended to be stuffed in a back pocket, ready to be used as a guide to sorting out some difficult dynamic.

Oppose and Propose is something between a compendium of source material and a history - what the author calls "militant co-research" meant to inspire modern organizers, both anarchists and others, and to help them avoid the pitfalls of their forbears. (Militant co-research seems to be a form of action research that involves one political organizer documenting the actions of others with their participation.) Mercifully, Oppose and Propose is not overly militant in style or tone and so is a remarkably accessible evocation of a self-consciously militant organization that has had a large, if largely forgotten, impact on the style and strategy of contemporary activism.

Formed in 1971 from A Quaker Action Group, Movement for a New Society was an activist network that combined Gandhian, Quaker, pacifist, civil rights, anarchist, socialist, feminist and environmentalist

\footnotetext{
${ }^{1}$ Our perspective on this book is heavily influenced by the fact that we live in one of the "prefigurative" institutions of MNS, the Life Center Association, a land-trusted housing association that provides cheap digs to activists. We are also members of the food coop MNS helped to start and cultivate several plots in the community garden. One of us worked for New Society Publishers for a dozen years, and we now do the decidedly unromantic (but rewarding) work of raising children in a collective household while trying to contribute as a professor and midwife to building a new society.
} 